\title{
Environmental damage costs from airborne pollution in the major cities in China
}

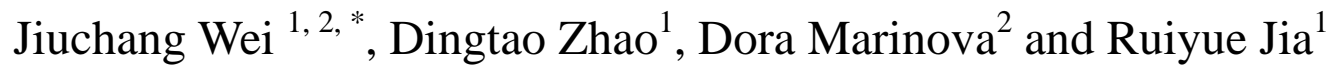 \\ ${ }^{1}$ School of Management, \\ University of Science and Technology of China, \\ 96 Jinzhai Road, Hefei City, Anhui Province, 230026, China \\ ${ }^{2}$ Curtin University Sustainability Policy Institute, \\ Curtin University of Technology, \\ GPO Box U1987, Perth WA 6845, Australia \\ E-mail:Weijc@ustc.edu.cn \\ E-mail: Box@ustc.edu.cn \\ E-mail: D.Marinova@curtin.edu.au \\ E-mail: Ryjia@mail.ustc.edu.cn \\ ${ }^{*}$ Corresponding author
}

Abstract: This paper estimates the environment external costs duo to air pollutants via the impacts pathway approach used for ExternE project in the major cities in China over the period 2003-2006. The estimation results show that the external costs were US\$ 20.15 billion in 2006, representing 2.28 percent of GDP (gross domestic product). This means that China suffered a lot for the air pollutants with the development of the economy. In the composition of external costs, damages to human health are the effects that generate the major part of externalities associated with air pollutants in these cities. The trend of external costs representing GDP in the sum of major cities was declining from 2003 to 2006, though the group in risk and agricultural products was increasing. Based on these finding, effective environmental policies and plans for economic development in these cities should focus not only on the volume of pollutants emission of $\mathrm{SO}_{2}$ and $\mathrm{PM}_{10}$, but also take other impact factors into account.

Keywords: environment external costs; impact pathway approach; IPA; the major cities in China; airborne pollution

Reference to this paper should be made as follows: Wei, J., Zhao, D., Marinova, D. and Jia, R. (xxxx) 'Environmental damage costs from airborne pollution in the major cities in China', Int. J. Environment and Sustainable Development, Vol. X, No. Y, pp.000-000.

Biographical notes: Jiuchang Wei is an Associate Professor in the School of Management at University of Science and Technology of China. Dingtao Zhao is a Professor in the School of Management at University of Science and Technology of China. Dora Marinova is a Professor in Curtin University Sustainability Policy Institute at Curtin University of Technology. Ruiyue Jia is a Ph.D. student in the School of Management at University of Science and Technology of China. 


\section{Introduction}

The production and application of technologies, for example for energy consumption, causes considerable damages to human health and on the natural and social environment (e.g. crops, forests, water resources, natural ecosystems, buildings, historical monuments, etc.). These impacts induce costs on society, which are called external costs or externalities.

An external cost which is related to social welfare and to the economy arises when the social or economic activities of one group of persons have an impact on another group and when that impact is not fully accounted, or compensated for, by the first group (European Commission, 2003). For example, a power station that generates emissions of $\mathrm{SO}_{2}$, causing damages on building materials or to human health, imposes an external cost. This is because the impact on the owners of the buildings or on those who suffer damages to their health is not taken into account by the generator of pollutants when deciding on the activities causing the damages.

It is important to value external costs in order for those values to be included in the design of policies to correct for the present lack of such property rights and markets. The estimation of the several types of externalities and the attribution of monetary values to a number of non-tradable goods such as human health, ecosystems, biodiversity, human amenity, etc., has been the subject of substantial effort for many years resulting in the development of a number of techniques based on welfare economic theories, namely Travel Cost Approach, Contingent Valuation method, Hedonic Pricing Approach, etc (Pearce and Turner, 1990; Freeman, 2003; Navrud, 2004). Contingent valuation is a survey method in which respondents are asked to state their preferences in hypothetical or contingent markets, allowing analysts to estimate demands for goods or services that are not traded in markets. The literature on the contingent valuation method's advantages and disadvantages is large (Mitchel and Carson, 1989; Bateman et al., 2002). A key problem to resolve in a contingent valuation study is to make the scenario sufficiently understandable, clear and meaningful to the respondent, who must understand clearly the changes in characteristics of the good or service he or she is being asked to value. Hedonic price analysis refers to the estimation of implicit prices for individual attributes of a market commodity when an environmental good or service can be viewed as attributes of a market commodity, such as properties or wages. Thus, just as wages are higher in risky occupations to compensate workers for their increased risks, property values may be lower in polluted areas to compensate residents for their increased risks. The property market is then used to infer the willingness to pay to reduce risks or disutility, through a hedonic price function. The implementation of most of these approaches requires significant human and economic resources, and the results obtained are to a large extent site-specific. Toward this, since the early 1990s, significant progress has been made through the utilization of results from various fields, namely environmental economics, epidemiology agronomy, etc. (Mirasgedis et al., 2008).

The ExternE project, initiated in 1992 and funded by the European Commission, was one of the first attempts aimed at establishing a consistent accounting framework for the assessment of externalities associated with various airborne pollution emission (European Commission, 2005; Carbonell et al., 2007; Rabl and Holland, 2008; Mirasgedis et al., 2008). This accounting idea is firstly to measure the damages to society which are not paid for by its 
main actors; secondly, to translate these damages into a monetary value; and thirdly, to explore how these external costs could be charged to the producers and consumers. Indeed, if the market takes into consideration the private costs, policy-makers should try to take into account the external costs (European Commission, 2003).

The methodology of ExternE project is based on a detailed bottom-up impact pathway approach. It was first implemented in the power generation sector in order to estimate the external costs associated with the electricity plant (European Commission, 1999). Now, the ExternE methodology is widely accepted by the scientific community and is considered as the world reference in the field (European Commission, 2005). Mirasgedis et al. (2008) applied this methodology to estimate the external costs attributable to the atmospheric pollution from 'medium and high environmental burden' industrial activities located in the greater Athens area. Gulli (2006) compared centralized and decentralized models of gas-fired power generations in terms of environmental external costs which calculated by the methodology of ExternE. In addition, a similar bottom-up methodology was also applied to estimate the environmental externalities caused by $\mathrm{SO}_{2}$ and $\mathrm{O}_{3}$ emitted from industrial and transport activities in Madrid (Lechon et al., 2002) and to evaluate the environmental performance of some specific industrial project in Taiyuan City in China (Mestl et al., 2005).

With a development of high speed in recent years, China has become one of the fastest economic growing countries in the world with the annual increases in GDP of 8 to 9 percent, but at the same time, China is also facing the worsening problem of pollution. Although the continued rapid growth is feasible, the growth demands and the environmental pressures it brings have raised grave concerns about the long-term sustainability and hidden costs of growth. Many of these concerns are associated with the impact of air and water pollution. Interest in the environment external costs research in China appears to have been shown up, with much of this attention focused on environmental damage costs from fossil electricity generation (Zhang et al., 2007), costs of air and water pollution estimates of physical damages in China during 2001-2005 (The World Bank, 2007), and case studies about environment damages in some cities (Wu et al.,2005; Mestl et al., 2005; Sun and Yang, 2007 ). These studies calculated environment external costs of China, industrial installations or a city, but seldom concerned about various cities and compared them.

Most of present studies have focused on external costs due to the pollution emissions of industries in one country or one area in one year, such as electricity plants, industrial sectors, and technologies. These studies contribute to solve a number of sustainability problems, but they fail to capture a series of potentially interesting features of dynamics of the external costs in a period in the comparisons of a number of areas. And the fact that the environment policy makers of government are concerned about is the damage costs of all the pollutants in one area, and the factors that cause the high concentration of air pollutants. It is highly desirable to subject proposed environmental strategies to a cost-benefit analysis to help avoid costly mistakes and ensure that our scarce resources are spent wisely.

This research highlights the environment external costs in the major cities in China, and examines the dynamics and geographical distribution features of external costs duo to $\mathrm{SO}_{2}$ and $\mathrm{PM}_{10}$ over the period 2003-2006 in each sample city which are valuable for effective environment policy making and the estimation of investment projects.

This paper is organized as follows. Section 2 presents the analytical approach of the 
external cost evaluation model and the data investigation about the major cities in China, and Section 3 describes the sample and the empirical findings. Finally, conclusions are provided in Section 4.

\section{Methodological background and data investigation}

\subsection{Approaches used for ExternE project}

The ExternE project uses the 'impact pathway approach (IPA)' for the assessment of the external impacts and associated costs resulting from the airborne emission (European Commission, 2005). The analysis proceeds sequentially through the pathway, as shown in Figure 1. Emissions and other types of burdens such as the risk of accidents are quantified and followed through to impact assessment and valuation. IPA thus provides a logical and transparent way of quantifying external costs.

Figure 1 The principal steps of an impacts pathway analysis, for the example of air pollution

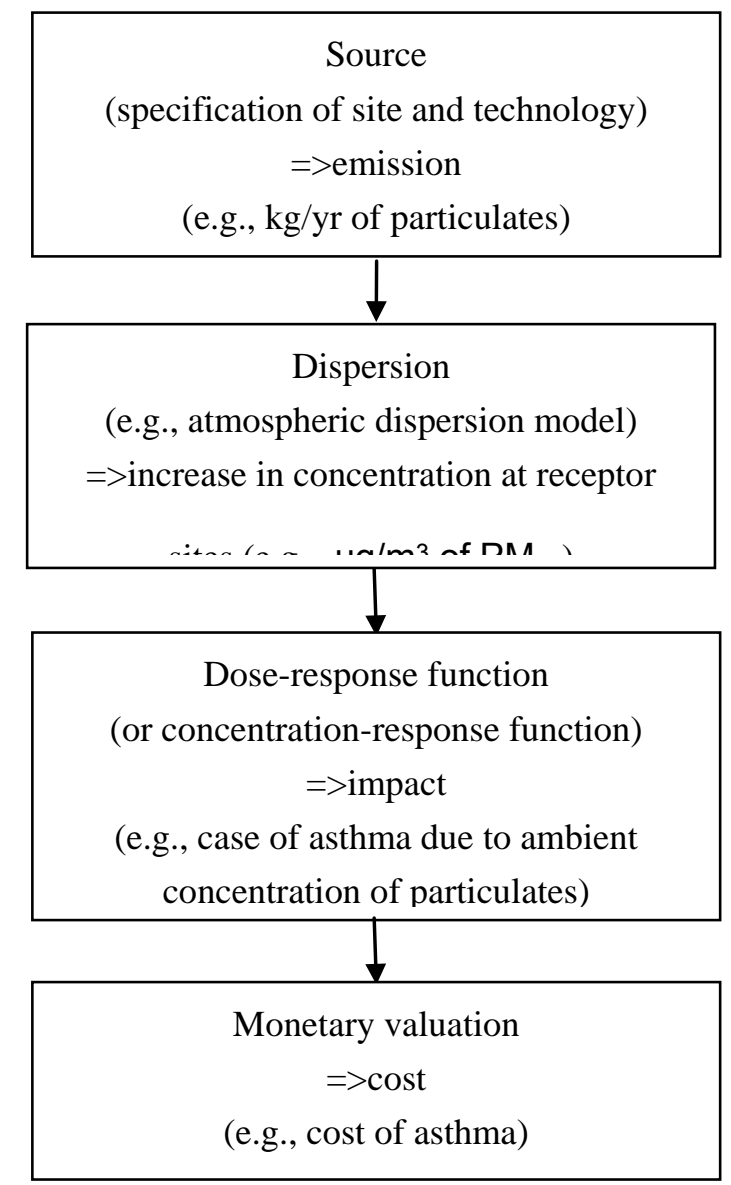

As illustrated in Figure 1, the principal steps of an IPA can be grouped as follows:

1 emission: specification of the relevant technologies and pollutants, for example, $\mathrm{kg}$ of oxides of particulates per GWh emitted by a power plant at a specific site

2 dispersion: calculation of increased pollutant concentrations in all affected regions, for example, incremental concentration of particulates, using models of atmospheric dispersion and chemistry for particulates formation

3 impact: calculation of the dose from the increased concentration, followed by 
calculation of impacts (damage in physical units) from this dose, using a dose-response function, for example, cases of asthma due to this increase in particulates

4 cost: economic valuation of these impacts, for example, multiplication by the cost of a case of asthma.

The impacts and costs are summed up over all receptors of concern. The work involves a multidisciplinary system analysis, with inputs from engineers, dispersion modelers, epidemiologists, ecologists and economists. For some burdens, for example, visual intrusion, the passage from burden to cost is more direct, without intermediate steps. The result of an IPA is the damage cost per burden. If the results are for a specific source of the burden, that should be indicated. IPA is the logically correct approach, but the details of the implementation differ between different studies (Rabl and Holland, 2008).

\subsection{Quantification of impacts and damages due to $P M_{10}$}

The impacts and damages due to $\mathrm{PM}_{10}$ are mainly on human health, included asthma attacks, hospital admissions, chronic bronchitis, restricted activity days, etc. The general approach to estimate the effects of $\mathrm{PM}_{10}$ on morbidity and mortality uses the relative risk found in epidemiological studies, expressed as \% change in $\mu \mathrm{g} / \mathrm{m}^{3}$. Results then expressed as estimated new or "extra" cases, events or days per year attributed to $\mathrm{PM}_{10}$.

In the context of present analysis the exposure-response functions proposed by the ExternE project (European Commission, 2005) have been used. But these functions were created by and for developed countries and their applications are limited for developing countries due to the complementary studies and large data requirements needed to estimate the impacts. Nevertheless, some data can be transferred from EeternE Project and other can be calculated or estimated by indirect ways, when no local data is available or the information is incomplete (Carbonell et al., 2007). In this research, we apply these dose-response functions and use Chinese Value per unit to replace European. The value per unit of Years of life lost due to chronic exposure is 50,000 European dollars, which is derived from an annual payment made over a ten-year period (European Commission, 2005). We use the annual payment in the major cities in China to replace the payment in European. The price of various morbidity values per unit in European is substituted by the price in China according to China Statistical Yearbook 2007 and China Health Statistical Yearbook 2007. The applied concentration-response functions are shown in Table 1.

Table 1 Quantification of human health impacts due to $\mathrm{PM}_{10}$

\begin{tabular}{ccc}
\hline Heath Effect & Risk Group & $\begin{array}{c}\text { Concentration-Response } \\
\text { Factor }\end{array}$ \\
\hline $\begin{array}{c}\text { Chronic mortality-Years of life lost due to } \\
\text { chronic exposure }\end{array}$ & ALL & 0.0004 \\
New cases of chronic bronchitis & Age $>27,63 \%$ & 0.0000265 \\
$\begin{array}{c}\text { Respiratory hospital admissions } \\
\text { Attributable emergency cardiac hospital } \\
\text { admissions }\end{array}$ & All & $7.03 \mathrm{E}-06$ \\
Restricted activity days & All & $4.34 \mathrm{E}-06$ \\
\hline
\end{tabular}


Symptom day(Lower respiratory symptoms including cough)

Days of lower respiratory symptoms, including cough, in children in the general population, i.e. extra symptoms days

Days of bronchodilator usage

$$
\begin{aligned}
& \text { Age }>18 \text { with chronic } \\
& \text { respiratory } \\
& \text { symptoms,25\% }
\end{aligned}
$$

Age 5 to $14,14.21 \%$

Age $>20$ with asthma, $4 \%$

Age 5 to 14 with asthma, $2 \%$

Note: The information presented in this table has been mainly derived by coSenseLE, European Commission (2005), China Statistical Yearbook 2007, China Health Statistical yearbook 2007. The concentration response factor is given in units of [cases/(year $\cdot$ person $\cdot \mu \mathrm{g} / \mathrm{m}^{3}$ )] for morbidity, and [\%change in annual mortality rate/( $\mu \mathrm{g} / \mathrm{m} 3)]$ for mortality.

\subsection{Quantification of impacts and damages due to $\mathrm{SO}_{2}$}

Impacts and damages due to $\mathrm{SO}_{2}$ are primary on agriculture and materials.

The function for effects from $\mathrm{SO}_{2}$ on agriculture, recommended in ExternE project is adapted from one derived by Baker et al. (1986). The function assumes that yield will increase with $\mathrm{SO}_{2}$ from 0 to $6.8 \mathrm{ppb}$, and decline thereafter. The function is used to quantify

\begin{tabular}{|c|c|c|}
\hline $\begin{array}{c}\text { Impact } \\
\text { category }\end{array}$ & Dose-response functions & Crop \\
\hline Yield & $0.74 \mathrm{x}_{\mathrm{SO}_{2}-}-0.055 \mathrm{x}_{\mathrm{SO} 2}^{2}\left(0<\mathrm{x}_{\mathrm{SO} 2}<13.6 \mathrm{ppb}\right)$ & Sunflower, wheat, Potato, Rice, Rye, Oats, \\
\hline loss & $-0.69 \mathrm{x}_{\mathrm{SO} 2}+9.35\left(\mathrm{x}_{\mathrm{SO} 2}>13.6 \mathrm{ppb}\right)$ & Tobacco, Barley Sugar beet \\
\hline
\end{tabular}
changes in crop yield for wheat, barley, potato, sugar beet, and oats, etc (see Table 2).

Table 2 Quantification of agriculture impacts due to $\mathrm{SO}_{2}$

Note: The information presented in this table has been mainly derived by coSenseLE, European Commission (2005).

The concentration-response functions used for impact assessment and recommended for ExternE (Friedrich and Bickel, 2001) are listed in Table 3 for different building materials. Apart from the concentration-response functions for carbonate paint (Haynie,1986), all are based on results from the UN_ECE ICP Materials (Kucera, Pearce and Brodin, 1997).

Table3 Quantification of materials impacts due to $\mathrm{SO}_{2}$

\begin{tabular}{cl}
\hline Material & \multicolumn{1}{c}{ Dose-response functions ${ }^{a}$} \\
\hline Limestone & $0.501 S\left(2.7 x_{\mathrm{SO}_{2}}^{0.48} e^{-0.018 T}+0.019 \operatorname{Rain}\left[H^{+}\right]\right)^{\frac{1}{0.96}}$ \\
$\begin{array}{c}\text { Sandstone, natural stone, mortar, } \\
\text { rendering }\end{array}$ & $0.311 S\left(2.0 x_{\mathrm{SO}_{2}}^{0.52} e^{f(T)}+0.028 R a i n\left[H^{+}\right]\right)^{\frac{1}{0.91}}$ \\
& With $\mathrm{f}(\mathrm{T})=0$ if T $<10^{\circ} \mathrm{C}$ \\
\hline
\end{tabular}




\begin{tabular}{cl}
\hline & or $f(T)=-0.013 \cdot(T-10) \quad$ if $\quad T>10^{\circ} \mathrm{C}$ \\
& $0.35367 S\left(x_{S_{2}}^{0.26} e^{0.021 R h} e^{f(T)}+1.04722 R a i n\left[H^{+}\right]\right)$ \\
Zinc and galvanized steel & With $\mathrm{f}(\mathrm{T})=0.073(\mathrm{~T}-10)$ if $\mathrm{T}<10^{\circ} \mathrm{C}$ \\
& or $\mathrm{f}(\mathrm{T})=-0.025(\mathrm{~T}-10) \quad$ if $\quad \mathrm{T}>10^{\circ} \mathrm{C}$ \\
& $2.427 \mathrm{~S}\left(0.033 x_{\mathrm{SO}_{2}}+0.013 R h+f(T)+0.0013 \operatorname{Rain}\left[H^{+}\right]\right)^{\frac{1}{0.41}}$ \\
Paint coating on steel & With $\mathrm{f}(\mathrm{T})=0.015(\mathrm{~T}-11)$ if $\mathrm{T}<11^{\circ} \mathrm{C}$ \\
& or $\mathrm{f}(\mathrm{T})=-0.15(\mathrm{~T}-11) \quad$ if $\quad \mathrm{T}>11^{\circ} \mathrm{C}$ \\
& $2.913 S\left(0.0084 x_{\mathrm{SO}_{2}}+0.015 R h+f(T)+0.00082 R a i n\left[H^{+}\right]\right)^{\frac{1}{0.43}}$ \\
Paint coating on galvanized steel & With $\mathrm{f}(\mathrm{T})=0.04(\mathrm{~T}-10)$ if $\mathrm{T}<10^{\circ} \mathrm{C}$ \\
& or $\mathrm{f}(\mathrm{T})=--0.064(\mathrm{~T}-10) \quad$ if $\quad \mathrm{T}>10^{\circ} \mathrm{C}$ \\
& $0.295 S\left(1-e^{\frac{-0.121 R h}{100-R h}}\right) x_{\mathrm{SO}_{2}}+0.0428 S R a i n\left[H^{+}\right]$ \\
\hline
\end{tabular}

Note: The information presented in this table has been mainly derived by coSenseLE, European Commission(2005).

${ }^{a} \mathrm{~S}$ is the surface recession in $\mu \mathrm{m} . \mathrm{X}_{\mathrm{SO}_{2}}$ is the $\mathrm{SO}_{2}$ concentration at receptors' site in $\mu \mathrm{g} / \mathrm{m} 3$, $\mathrm{T}$ is the temperature in ${ }^{\circ} \mathrm{C}$. Rain is the precipitation in mm/year. $\left[\mathrm{H}^{+}\right]$is the hydrogenation concentration in precipitation expressed in $\mathrm{mg} / \mathrm{l}$. $\mathrm{Rh}$ is the relative humidity in \%.

\subsection{Data collection}

Using the approach developed above, we calculate environment external costs and analyze the policy applications in 30 major cities in China that includes Beijing, Shanghai, Tianjin, Chongqing, Wuhan, etc. We collected the data of the ambient concentrations of $\mathrm{SO}_{2}$ and $\mathrm{PM}_{10}$, the amount of risk group, the unit damage cost of mortality and morbidity, the price of crop and material, and the temperature, the precipitation, and the hydrogenation in each major city. The data for this study was drawn from three sources, namely, China Statistical Yearbook (2004-2007), China Health Statistical Yearbook (2004-2007) and China Environment Statistical Yearbook (2004-2007).

The pivotal data about $\mathrm{SO}_{2}$ and $\mathrm{PM}_{10}$ are shown in Table 4. For the data limited, we can only collect the ambient concentration of $\mathrm{SO}_{2}$ and $\mathrm{PM}_{10}$ in each major city for the period 2003-2006.

Table 4 Concentrations of $\mathrm{SO}_{2}$ and $\mathrm{PM}_{10}$ in major cities in China (2003-2006)

\begin{tabular}{lccccccccc}
\hline & & 2003 & 2004 & 2005 & 2006 & 2003 & 2004 & 2005 & 2006 \\
\cline { 3 - 10 }$I D$ & \multirow{2}{*}{ City } & $\begin{array}{c}\mathrm{SO}_{2} \\
(\mathrm{ppb})\end{array}$ & $\begin{array}{c}\mathrm{SO}_{2} \\
(\mathrm{ppb})\end{array}$ & $\begin{array}{c}\mathrm{SO}_{2} \\
(\mathrm{ppb})\end{array}$ & $\begin{array}{c}\mathrm{SO}_{2} \\
(\mathrm{ppb})\end{array}$ & $\begin{array}{c}\mathrm{PM}_{10} \\
\left(\mu \mathrm{g} / \mathrm{m}^{3}\right)\end{array}$ & $\begin{array}{c}\mathrm{PM}_{10} \\
\left(\mu \mathrm{g} / \mathrm{m}^{3}\right)\end{array}$ & $\begin{array}{c}\mathrm{PM}_{10} \\
\left(\mu \mathrm{g} / \mathrm{m}^{3}\right)\end{array}$ & $\begin{array}{c}\mathrm{PM}_{10} \\
\left(\mu \mathrm{g} / \mathrm{m}^{3}\right)\end{array}$ \\
\hline 1. & Beijing & 21.35 & 19.25 & 17.5 & 18.2 & 141 & 149 & 141 & 162 \\
2. & Changchun & 4.2 & 4.55 & 9.1 & 9.1 & 98 & 85 & 99 & 99 \\
3. & Changsha & 28.35 & 29.4 & 28.35 & 28.7 & 135 & 140 & 122 & 111 \\
\hline
\end{tabular}




\begin{tabular}{|c|c|c|c|c|c|c|c|c|c|}
\hline 4. & Chengdu & 18.2 & 23.45 & 26.95 & 22.75 & 118 & 115 & 125 & 123 \\
\hline 5. & Chongqing & 40.25 & 39.55 & 25.55 & 25.9 & 147 & 142 & 120 & 111 \\
\hline 6. & Fuzhou & 2.8 & 3.5 & 5.6 & 7 & 80 & 74 & 72 & 72 \\
\hline 7. & Guangzhou & 20.65 & 26.95 & 18.55 & 18.9 & 99 & 99 & 88 & 76 \\
\hline 8. & Guiyang & 31.15 & 32.9 & 22.05 & 22.75 & 104 & 83 & 76 & 83 \\
\hline 9. & Haerbin & 15.05 & 14.7 & 14.7 & 11.9 & 121 & 113 & 104 & 104 \\
\hline 10. & Haikou & 3.15 & 2.45 & 4.2 & 3.5 & 30 & 33 & 40 & 41 \\
\hline 11. & Hangzhou & 17.15 & 17.15 & 21 & 19.6 & 119 & 110 & 112 & 111 \\
\hline 12. & Hefei & 4.2 & 4.55 & 6.3 & 8.4 & 100 & 110 & 95 & 99 \\
\hline 13. & Huhhot & 13.65 & 15.75 & 17.5 & 18.9 & 116 & 80 & 97 & 102 \\
\hline 14. & Jinan & 22.4 & 15.75 & 21 & 14 & 149 & 149 & 128 & 114 \\
\hline 15. & Kunming & 15.75 & 24.15 & 19.25 & 21.7 & 86 & 85 & 82 & 91 \\
\hline 16. & Lanzhou & 30.1 & 24.85 & 23.8 & 19.95 & 174 & 172 & 158 & 192 \\
\hline 17. & Nanchang & 17.85 & 19.95 & 17.5 & 19.6 & 100 & 99 & 89 & 86 \\
\hline 18. & Nanjing & 10.5 & 15.75 & 18.2 & 22.05 & 120 & 121 & 110 & 109 \\
\hline 19. & Nanning & 16.45 & 21.35 & 20.3 & 20.65 & 72 & 78 & 67 & 66 \\
\hline 20. & Shanghai & 15.05 & 19.25 & 21.35 & 17.85 & 97 & 99 & 88 & 86 \\
\hline 21. & Shenyang & 18.2 & 18.2 & 18.9 & 20.3 & 135 & 137 & 118 & 117 \\
\hline 22. & Shijiazhuang & 53.2 & 30.45 & 18.9 & 15.4 & 175 & 123 & 132 & 142 \\
\hline 23. & Taiyuan & 34.65 & 30.45 & 26.95 & 28 & 172 & 175 & 139 & 142 \\
\hline 24. & Tianjin & 25.9 & 25.55 & 26.6 & 23.45 & 133 & 111 & 106 & 114 \\
\hline 25. & Urumqi & 33.95 & 35.7 & 40.6 & 39.55 & 127 & 114 & 114 & 152 \\
\hline 26. & Wuhan & 17.15 & 16.8 & 18.9 & 19.95 & 133 & 130 & 119 & 121 \\
\hline 27. & Xi'an & 19.95 & 17.15 & 15.4 & 19.6 & 136 & 142 & 129 & 133 \\
\hline 28. & Xining & 10.85 & 8.4 & 10.15 & 8.4 & 139 & 127 & 114 & 135 \\
\hline 29. & Yinchuan & 22.05 & 18.9 & 18.9 & 16.8 & 132 & 122 & 90 & 97 \\
\hline \multirow[t]{2}{*}{30.} & Zhengzhou & 17.5 & 19.95 & 20.65 & 21 & 107 & 111 & 109 & 111 \\
\hline & Sample Median & 18.025 & 19.25 & 18.9 & 19.6 & 120.5 & 113.5 & 109.5 & 111 \\
\hline
\end{tabular}

Note: The information presented in this table has been mainly derived from the China Environment Statistical yearbook (2004-2007). For the reason of data collection, Lhasa, Hong Kong, Macao and Taipei were not included.

The 30 cities are all the capitals of corresponding provinces, as figures 4 shows. They play important roles in the development of China's economy and society. In 2006, the aggregated GDP (gross domestic product) of the cities was US\$ 882.25 billion, amounting for 33.36 percent of China's GDP, and the population in suburbs was 91.81 million, amounting for 6.88 percent of China's population. As shown in Table 4, the median of $\mathrm{SO}_{2}$ concentrations increased from $18.025 \mathrm{ppb}$ to $19.6 \mathrm{ppb}$ for the period 2003-2006, and the median of $\mathrm{PM}_{10}$ concentrations reduced from $120.5 \mu \mathrm{g} / \mathrm{m}^{3}$ to $111 \mu \mathrm{g} / \mathrm{m}^{3}$.

\section{Applications and results}

The methodological framework described previously was implemented in 30 major cities based on the collected data. We can elicit the value of environment external costs and other findings as follows. 
3.1 Disaggregation of the total external costs estimates attributed to the air pollutants

To prioritize different possible actions, one needs to know which source of pollution causes how much damage (Rabl et al., 2007). Table 5 and Figure 2 show the annual statistics on the environment external costs for the 30 major cities as a whole included in this study. The fluctuation range of the external costs was little, namely US\$ 19.47-20.15 billion during the period 2003-2006. There was an overall upward trend in external costs during this period. For the 30 cities as a whole, external costs increased by 3.49\% between 2003 and 2006. There were 17 cities where the concentration of $\mathrm{SO}_{2}$ increased, but the concentration of $\mathrm{SO}_{2}$ in the major metropolises, such as Beijing, Tianjin, Chongqing, reduced. On the contrary, there were 23 cities where the concentration of $\mathrm{PM}_{10}$ reduced.

Though the pollutants in the cities mitigated, the external costs still ascended. The reason is that the amount of risk group, the crop productions and the building materials increased. Over the period 2003-2006, population at risk grew by 7.98\% (82.29-91.81 million), and agriculture productions grew $11.57 \%$ and construction floor space of housing grew up $14.1 \%$.

Table 5 Disaggregation of external costs estimates attributed to the air pollutants (2003-2006, Billion US\$)

\begin{tabular}{ccccc}
\hline External costs & 2003 & 2004 & 2005 & 2006 \\
\hline Health Loss & 17.33 & 17.44 & 16.74 & 17.82 \\
Crops Loss & 0.61 & 0.68 & 0.67 & 0.61 \\
Building Material loss & 1.54 & 1.56 & 1.67 & 1.73 \\
Total & 19.47 & 19.67 & 19.08 & 20.15 \\
\hline
\end{tabular}

Figure2 Disaggregation proportion of external costs estimates attributed to the air pollutants (2003-2006) (see online version for colours)

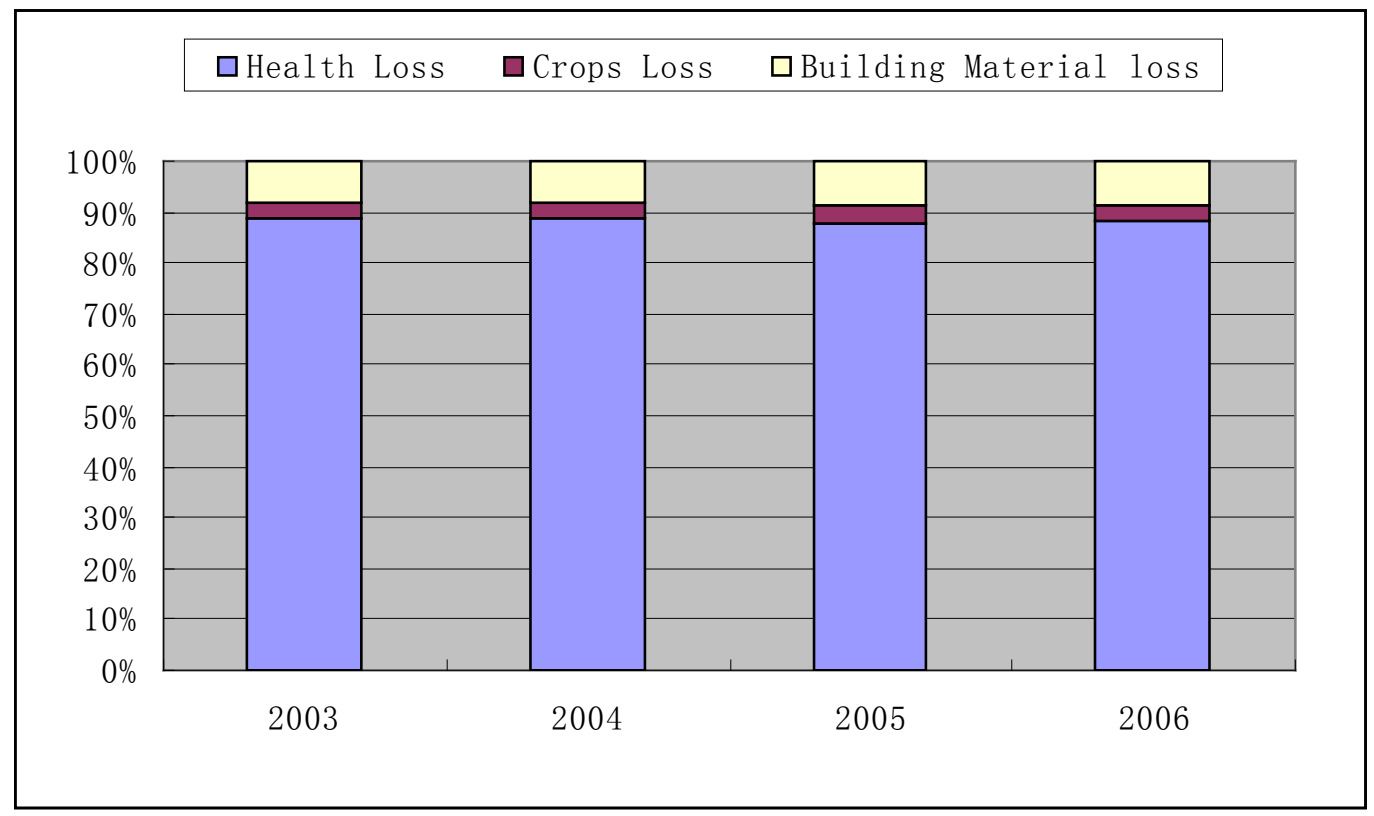


As shown in Figure 2, damages to public health are the effects that generate the major part of externalities associated with air pollutants in these cities. In 2006, the health loss due to $\mathrm{PM}_{10}$ was US $\$ 17.82$ billion, amounting for $88.41 \%$ of the external costs. The health loss in 2006 was larger than in any other year and increased by $2.82 \%$ from 2003 to 2006 . The reason for the growth of health loss is primarily the population increasing by 7.98\% from 2003 to 2006 though the $\mathrm{PM}_{10}$ pollutants descended. Impacts on building material were less than $10 \%$, but it increased from $7.91 \%$ to $8.57 \%$ during 2003-2006, and the concentration of $\mathrm{SO}_{2}$ of 17 cities ascended. The impacts on agriculture were less than on public health and building materials. The costs of agriculture loss decreased from 2004 to 2006. It was mainly because the concentration of $\mathrm{SO}_{2}$ in 18 cities declined.

\subsection{GDP and external costs in 30 major cities}

In recent decades, the major cities have achieved rapid economic growth. In 2006, the average increase in GDP was $15.56 \%$. Alongside economic growth, the utilization of technology improvements and the implementation of environmental pollution control policies have contributed substantially to leveling off or even reducing pollution loads in the major cities. At the same time, new challenges have been created (The World Bank, 2007). With the urban population increasing, the risk group facing environment pollutants are ascending. More building materials are being affected by the $\mathrm{SO}_{2}$. Moreover, between 2003 and 2006, air pollution emissions had remained constant or increased in some cities. Study on the relationship between the economic growth and environment costs provides relevant and valuable information of hidden costs of growth and the development of sustainability.

We used the ratio of external costs to GDP (RECGDP) as the measure of the sustainability of economic growth in each city. The value of RECGDP indicates the proportion of the income is offset by air pollutants, as shown in Table 6. The fluctuation range of RECGP was from $0.23 \%$ to $12.05 \%$ during 2003 to 2006. The highest RECGDP was in Xining in 2003, while the lowest was in Fuzhou in 2006. Though the external costs showed an overall upward trend, RECGDP decreased from $3.71 \%$ to $2.28 \%$ and showed a significantly downward trend from 2003 to 2006. It indicated that the economic growth in 30 cities was faster than the increase in external costs and more sustainability than before.

Table 6 The value of RECGDP (external costs/GDP, \%) in major cities in China

\begin{tabular}{ccrrrrrrc}
\hline ID & City & 2003 & 2004 & 2005 & 2006 & Average & Class & Trend of RECGDP \\
\hline 1 & Fuzhou & 1.08 & 0.57 & 0.25 & 0.23 & 0.53 & I & Reducing \\
2 & Haikou & 1.19 & 1.30 & 1.32 & 1.54 & 1.34 & I & Increasing \\
3 & Guangzhou & 1.99 & 1.85 & 1.30 & 1.01 & 1.54 & I & Reducing \\
4 & Hangzhou & 1.95 & 1.64 & 1.58 & 1.32 & 1.62 & I & Reducing \\
5 & Shanghai & 2.42 & 2.23 & 1.77 & 1.53 & 1.99 & I & Not clear \\
6 & Changchun & 2.44 & 1.90 & 2.09 & 2.08 & 2.13 & I & Not clear \\
7 & Nanning & 2.60 & 2.65 & 1.86 & 1.52 & 2.16 & II & Reducing \\
8 & Zhengzhou & 2.64 & 2.33 & 2.01 & 1.68 & 2.17 & II & Reducing \\
9 & Huhhot & 3.53 & 2.04 & 1.69 & 1.54 & 2.20 & II & Reducing \\
10 & Kunming & 2.63 & 2.47 & 2.07 & 2.11 & 2.32 & II & Reducing \\
11 & Nanchang & 3.53 & 3.09 & 2.21 & 1.93 & 2.69 & II & Reducing \\
\hline
\end{tabular}




\begin{tabular}{lcrrrrrrl}
\hline 12 & Chengdu & 2.67 & 2.69 & 3.14 & 2.71 & 2.80 & II & Increasing \\
13 & Hefei & 3.58 & 3.49 & 2.38 & 2.08 & 2.88 & II & Reducing \\
14 & Changsha & 3.73 & 3.33 & 2.31 & 2.13 & 2.88 & II & Reducing \\
15 & Haerbin & 3.60 & 3.10 & 2.85 & 2.50 & 3.01 & II & Reducing \\
16 & Jinan & 4.02 & 3.35 & 2.74 & 2.05 & 3.04 & II & Reducing \\
17 & Tianjin & 4.44 & 3.19 & 2.49 & 2.26 & 3.10 & II & Reducing \\
18 & Shijiazhuang & 4.75 & 2.86 & 2.55 & 2.42 & 3.15 & II & Reducing \\
19 & Nanjing & 4.07 & 3.69 & 2.92 & 2.72 & 3.35 & II & Reducing \\
20 & Chongqing & 4.50 & 3.87 & 2.87 & 2.44 & 3.42 & II & Reducing \\
21 & Beijing & 4.82 & 4.37 & 2.64 & 2.73 & 3.64 & II & Reducing \\
22 & Shenyang & 5.06 & 4.39 & 3.60 & 3.08 & 4.03 & III & Reducing \\
23 & Guiyang & 6.18 & 4.62 & 3.45 & 3.36 & 4.40 & III & Reducing \\
24 & Wuhan & 5.54 & 4.70 & 3.96 & 3.64 & 4.46 & III & Reducing \\
25 & Xi'an & 6.15 & 5.53 & 4.48 & 4.23 & 5.10 & IV & Reducing \\
26 & Yinchuan & 7.98 & 6.37 & 3.40 & 3.19 & 5.24 & IV & Reducing \\
27 & Urumqi & 8.11 & 6.58 & 6.41 & 6.97 & 7.02 & V & Reducing \\
28 & Taiyuan & 10.64 & 8.67 & 5.16 & 5.07 & 7.39 & V & Reducing \\
29 & Xining & 12.05 & 9.15 & 6.27 & 6.43 & 8.48 & V & Reducing \\
30 & Lanzhou & 10.05 & 8.79 & 7.48 & 7.95 & 8.57 & V & Reducing \\
& Average & 3.71 & 3.17 & 2.50 & 2.28 & 2.91 & - & Reducing \\
\hline
\end{tabular}

It is important and valuable to examine the geographical distribution features of external costs in these cities. For the sample size $\mathrm{N}$ is 30 , we group them by the method of the interval grouping. In terms of the sample size and research issue (Spiegel and Stephens, 1999.; Frankfort-Nachmias and Leon-Guerrero, 2008), we divide them into 5 groups by the variable of the average of RECGDP. The range of data is $8.4 \%$ and the class interval is $1.608 \%$. The grouping result was marked in the map, as shown in Figure 3. 
Figure 3 The map of groups of these cities in China due to RECGDP (see online version for colours)

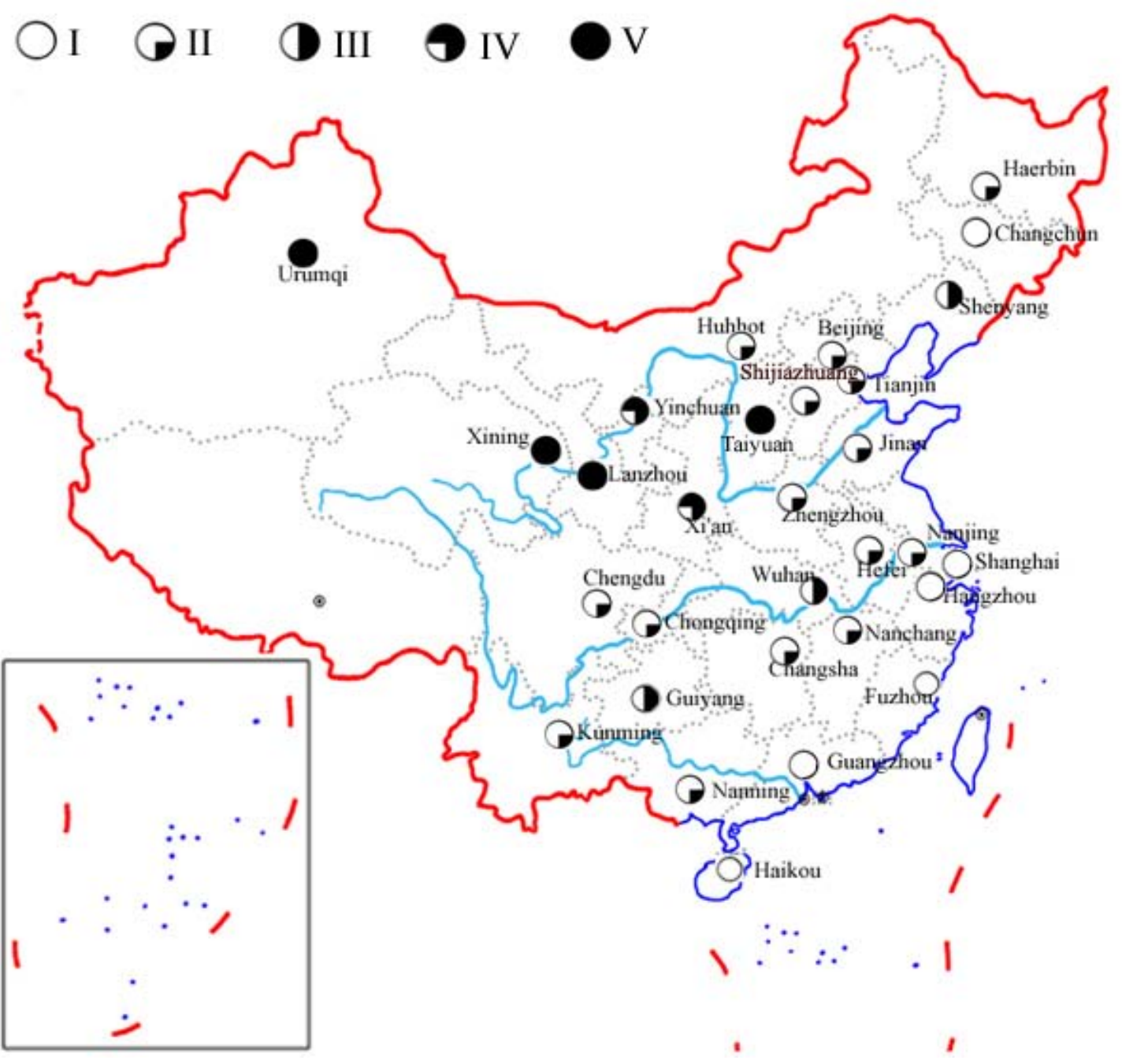

Group I $\quad 0.53 \% \leq \mathrm{RECGDP}<2.138 \%$. This group consists of Fuzhou, Haikou, Guangzhou, Hangzhou, Shanghai and Changchun. The 6 cities where the RECGDP is all below 2.138\% locate near the sea. Most of them had lower ambient concentrations of $\mathrm{SO}_{2}$ and $\mathrm{PM}_{10}$, especially Haikou, Fuzhou and Changchun. And per capital GDP of Shanghai and Guangzhou was highest among all the cities in 2006. Hangzhou had the $4^{\text {th }}$ highest per capital GDP. The reasons presented above resulted in the low RECGDP in the 6 cities.

Group II $\quad 2.138 \% \leq$ RECGDP $<3.746 \%$. Among this group, the external costs represent less than $3.746 \%$ of the GDP. It consists of 15 cities, including Beijing, Chongqing, Nanjing, Shijiazhuang etc, and most of them lie in the Middle and West-South China. This is a biggest group. The concentrations of $\mathrm{SO}_{2}$ or $\mathrm{PM}_{10}$ were low in some cities with low per capita GDP, such as Nanchang, Hefei, and Kunming. And the per capita GDP in some cities with serious pollution were much higher, such as Beijing, Chengdu, Tianjin and Changsha.

Group III 3.746\% $\leq$ RECGDP $<5.354 \%$. There are 3 cities in Group III, respectively Wuhan, Guiyang and Shenyang. The concentrations of $\mathrm{SO}_{2}$ or $\mathrm{PM}_{10}$ in the 3 cities were 
much higher than the sample median, for example, Guiyang had high concentrations of $\mathrm{SO}_{2}$, Wuhan and Shenyang had high concentrations of $\mathrm{PM}_{10}$. This contributed to their external costs. In 2006, the per capita GDP in the 3 cities was much lower than the average US\$4619 of the 30 cities.

Group IV 5.354\% $\leq$ RECGDP $<6.962 \%$. This group consists of Yinchuan and Xi' an that lie in Western China. In 2006, the per capita GDP in Yinchuan and Xi'an were much lower than the average US\$4619 of the 30 cities, respectively US\$2573 and US\$2148. The concentration $\mathrm{PM}_{10}$ in Xi'an was much higher than the sample median about $111 \mu \mathrm{g} / \mathrm{m}^{3}$.Though the air pollution was not serious in Yinchuan in 2006, but it was more serious between 2003 and 2004.

Group V $6.962 \% \leq$ RECGDP $\leq 8.57 \%$. This group consists of Lanzhou, Xining, Taiyuan and Urumqi, whose RECGDP was all over 7\%. They have highest RECGDP that indicated the economic growth was offset by the external cost in the 4 cities. Cities in Group V are similar to Group IV that also lie in Western and Middle China. They have serious air pollution and a low level of economic development. The concentration of $\mathrm{SO}_{2}$ in Urumqi was always in excess of 33.95ppb during the period 2003-2006 and got the largest value in these cities in 2006. This resulted in huge damages on agriculture and building materials. The concentration of $\mathrm{PM}_{10}$ in the 4 cities was much higher than the sample median in 2006. Especially in Lanzhou, it was $192 \mu \mathrm{g} / \mathrm{m}^{3}$ with the highest concentration. At the same time, the per capita GDP was much lower than the average US $\$ 4619$ of 30 cities.

As table 6 shows, for the 30 cities as a whole, GDP growth outpaced that of the environment external costs during the period 2003-2006, and we can say that the development of major cities in China is becoming more sustainable. For the period 2003-2006, the trend of RECGDP was stable in Group I, but it was decreasing quickly in Group IV and Group V. Figure 4 shows geographical differences in RECGDP of 30 cities. Group V and Group IV which have low sustainability all lie in Western and Central China. The cities in Group I locate near the sea have much more sustainability than others in Group V and Group IV that lie in Central China and Western China. It indicates that the geographical distribution is an important factor that affected RECGDP.

\subsection{Marginal external costs of $\mathrm{SO}_{2}$ and $\mathrm{PM}_{10}$ due to industry}

In recent years, $\mathrm{SO}_{2}$ and $\mathrm{PM}_{10}$ emissions from industrial processes have represented preponderance in China. Volume of $\mathrm{SO}_{2}$ emission by industry was 22.35 billion tons in 2006, represented $86.33 \%$ of the total $\mathrm{SO}_{2}$ emission. At the same time, the volume of industrial soot emission from industry amounted for $79.39 \%$ of total soot emission. Industrial activities were the major pollutants resources.

In different cities, the same volume of air pollutants emission contributed to industry leads to different environment external costs. In order to control the pollutants with effective and an economical strategy, we should analyze the External Costs per Ton of Pollutants (ECTP) and Marginal External Costs of Pollutants (MECP) in each city. ECTP means the external costs caused by per ton of pollutants. MECP is the change in the external costs that arise when the quantity of pollutants changes by one unit. 
Table 7 ECTP and MECP of $\mathrm{SO}_{2}$ and $\mathrm{PM}_{10}$ in 2006

\begin{tabular}{|c|c|c|c|c|c|}
\hline City & $\begin{array}{c}\operatorname{ECTP}\left(\mathrm{SO}_{2}\right) \\
\text { (US\$1000/ton) }\end{array}$ & $\begin{array}{c}\operatorname{MECP}\left(\mathrm{SO}_{2}\right) \\
\text { (US\$1000/ton) }\end{array}$ & City & $\begin{array}{c}\operatorname{ECTP}\left(P_{10}\right) \\
\text { (US\$1000/ton) }\end{array}$ & $\begin{array}{l}\text { MECP }\left(P M_{10}\right) \\
\text { (US\$1000/ton) }\end{array}$ \\
\hline Beijing & 2.56 & -1.02 & Fuzhou & 296.72 & 0.00 \\
\hline Shenyang & 1.81 & 0.43 & Guangzhou & 267.35 & 39.42 \\
\hline Changsha & 1.71 & -0.11 & Shanghai & 178.69 & 38.64 \\
\hline Urumqi & 1.33 & -0.24 & Shenyang & 125.87 & 2.31 \\
\hline Yinchuan & 1.17 & 9.17 & Tianjin & 104.35 & -8.30 \\
\hline Nanchang & 1.08 & 0.93 & Beijing & 81.57 & -133.91 \\
\hline Haerbin & 1.00 & -27.87 & Hefei & 77.91 & -103.14 \\
\hline Nanjing & 0.92 & -7.96 & Wuhan & 77.49 & -41.80 \\
\hline Chengdu & 0.88 & 13.56 & Yinchuan & 56.26 & -7.02 \\
\hline Guangzhou & 0.87 & -0.16 & Urumqi & 41.50 & -89.13 \\
\hline Lanzhou & 0.75 & -1.03 & Xi'an & 36.58 & -3.36 \\
\hline Wuhan & 0.75 & -6.20 & Nanchang & 33.54 & 37.14 \\
\hline Shanghai & 0.74 & 61.88 & Chengdu & 31.89 & 2.02 \\
\hline Taiyuan & 0.71 & -0.15 & Kunming & 30.51 & 32.96 \\
\hline Tianjin & 0.71 & 3.12 & Jinan & 18.74 & 41.19 \\
\hline Hangzhou & 0.68 & 2.18 & Changchun & 17.16 & 0.00 \\
\hline Xi'an & 0.68 & 5.93 & Haerbin & 16.24 & 0.00 \\
\hline Changchun & 0.51 & 0.00 & Nanjing & 16.17 & 0.88 \\
\hline Jinan & 0.51 & 31.45 & Lanzhou & 16.12 & 5.39 \\
\hline Nanning & 0.51 & -1.84 & Taiyuan & 14.97 & -16.64 \\
\hline Kunming & 0.44 & 7.69 & Hangzhou & 10.22 & 0.35 \\
\hline Zhengzhou & 0.36 & -0.21 & Guiyang & 9.83 & -1.54 \\
\hline Hefei & 0.28 & 0.73 & Huhhot & 8.37 & 7.09 \\
\hline Huhhot & 0.21 & 0.23 & Xining & 6.82 & -10.40 \\
\hline Shijiazhuang & 0.21 & -0.54 & Zhengzhou & 5.10 & -0.31 \\
\hline Guiyang & 0.19 & -0.04 & Chongqing & 4.68 & 6.55 \\
\hline Chongqing & 0.18 & 0.06 & Nanning & 4.34 & 0.31 \\
\hline Xining & 0.11 & -0.77 & Shijiazhuang & 4.06 & -4.16 \\
\hline Fuzhou & -0.13 & 0.00 & Changsha & 3.84 & -13.66 \\
\hline Haikou & -50.17 & 26.88 & Haikou & - & - \\
\hline
\end{tabular}

With the external costs increasing in 30 cities, we should take measures to deal with the pollutants. As shown in Table 7, each city has different ECTP and MECP. It shows that the reduction in per ton air pollutants (e.g. $\mathrm{PM}_{10}, \mathrm{SO}_{2}$ ) will change different external costs in each city. Supposing the costs of per ton of air pollutants removed are equal in each city, an optimal air pollutants control strategy can be proposed based ECTP and MECP. Figure 4 and Figure5 show the scatter graph of MECP and ECTP about $\mathrm{SO}_{2}$ and $\mathrm{PM}_{10}$. MECP is X-axis, and ECTP is y-axis. 
Figure 4 The scatter graph of MECP- $\mathrm{SO}_{2}$ and ECTP- $\mathrm{SO}_{2}$ in 2006

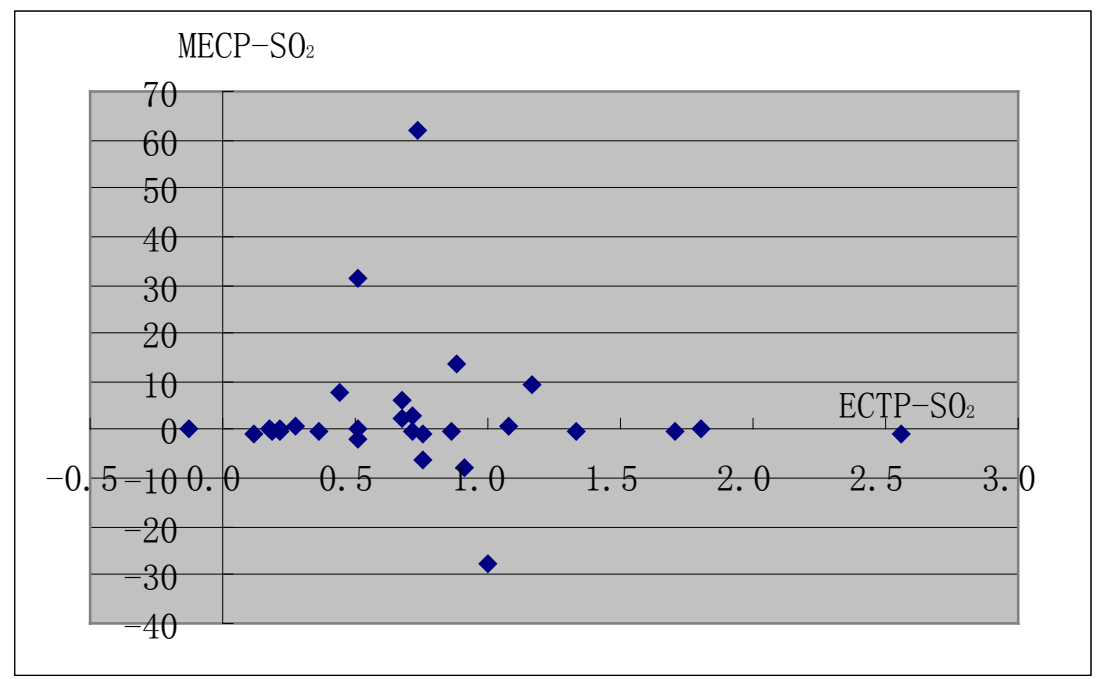

Figure 5 The scatter graph of MECP- PM $_{10}$ and ECTP- PM 10 in 2006

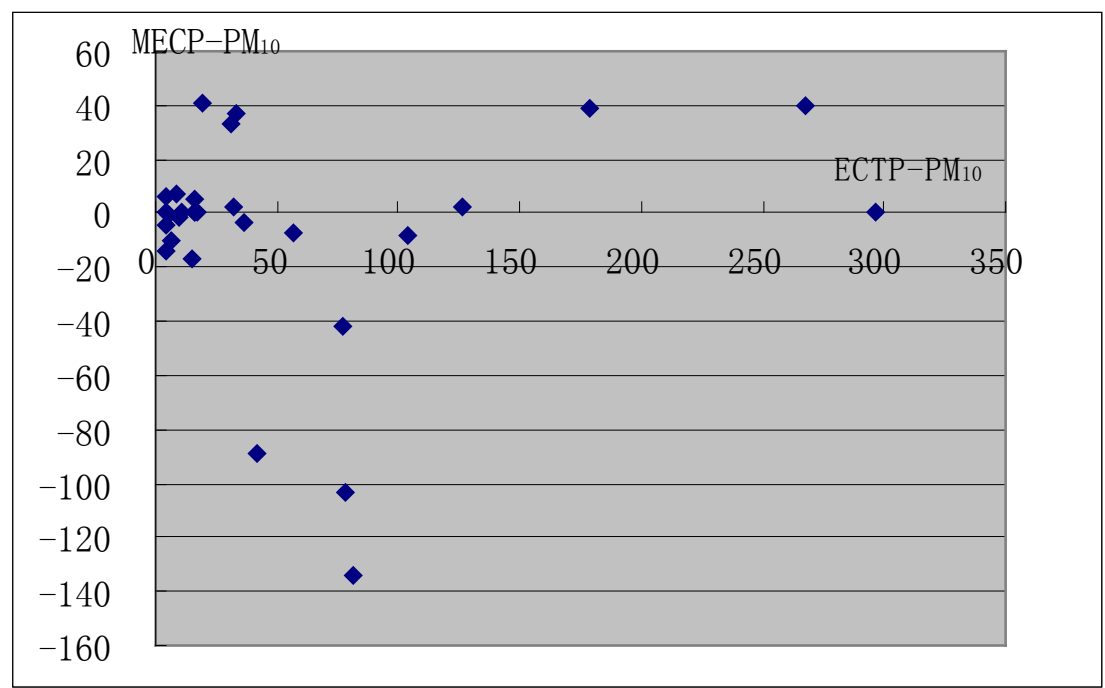

Generally, we need to pay more attention to the cities that have the high ECTP because per ton pollutants will cause the high external costs. The government will finance the application of the new technology to reduce the pollutants emissions in these cities. But sometimes emission reduction would not make the external costs decrease. As Table 7 and Figure 4 show, some cities has positive MECP that means external costs would reduce with the decreasing in pollutants emissions. It is effective to invest or apply new technology to reduce pollutants emissions from industrial installations in these cities, such in Shanghai, Guangzhou, Nanchang, Kunming, Jinan. This pollution treatment would be economic for the whole perspective.

But some cities have negative MECP, such as Beijing, Haerbin,Wuhan, etc. It indicates that the external costs would not descend with the decrease of pollutants emissions, so there are some other factors that significantly influence the air pollutants dispersing, such as temperature, precipitation, relative humidity, urban building features, etc. To control the air pollution in these cities, we should take various measures based on these factors to mitigate 
the concentration of air pollutants, or redesign the development plan of city according to these factors.

\section{Conclusions}

In this research, the IPA method for estimating the environmental externalities associated with air pollutants has been applied in the major cities in China. Attributing monetary values to assess the external costs of the primary air pollutants- $\mathrm{SO}_{2}$ and $\mathrm{PM}_{10}$ by the methodology of ExternE Project, we calculate and analyze the external costs in 30 cities over the period 2003-2006.

The examined results clearly show that external costs associated with air pollutants are very large and amount to US\$ 20.15 billion, representing 2.28\% of the GDP in the sum of 30 cities. These externalities are associated mainly with human mortality and morbidity primarily due to $\mathrm{PM}_{10}$ emissions, and agriculture loss and materials loss due to $\mathrm{SO}_{2}$ emissions. Nevertheless, the trend of external costs representing GDP in the sum of 30 cities was declining from 2003 to 2006, though the risk groups and agriculture products were increasing. It appears that external costs representing GDP in the cities that lie in Eastern China was less than in Central China, less than Western China or Western-south China.

The estimation of external costs benefits the process of effective air pollution regulations (Matus et al., 2008). Based on these findings, effective environmental policies and plans for industrial development in these cities should not only focus on the volume of pollutants emission of $\mathrm{SO}_{2}$ and $\mathrm{PM}_{10}$, but also take other impact factors into account.

Although analysis of external costs must be used with caution, and not as the only criterion for a decision, it does provide a valuable framework to help clarify the external costs contributed to economic development and effective environment policy making.

\section{Acknowledgement}

This paper Supported by the grant of Chinese National Planning Office of Philosophy and Social Science (No. 06BJL064) and Social Science Foundation of Chinese Ministry of Education (06JC630026).

\section{References}

Baker, C.K., Colls, J.J., Fullwoo, A.E., and Seaton G.G.R. (1986) 'Depression of growth and yield in winter barley exposed to sulphur dioxide in the field', New Phytologist, vol. 104, pp. 233-241.

Bateman, I.J., Carson, R.T., Day, B. et al., 2002. Economic Valuation with State Preference Technique: a manual. Edward Elgar, Cheltenham.

Carbonell, L.T., Ruiz, E.M., Gacita, M.S., Oliva, J.R. and Rivero, N.D. (2007) 'Assessment of the impacts on health due to the emissions of Cuban power plants that use fossil fuel oil with high content of sulfur. Estimation of external costs', Atmoshperic Environment, vol.41, pp.2202-2213.

European Commission (1999) ExternE: externalities of energy - Vol. 10, national 
implementation, Prepared by CIEMAT, EUR 18528, Brussels.

European Commission (2003) ECOSIT: external costs of innovative industrial technologies, CSG programme of the EC, final report; Project N. GMAI 2000-27006.

European Commission (2005) Reference document on economics and cross-media effects, Seville Spain, DG JRC.

Frankfort-Nachmias, C. and Leon-Guerrero, A. (2008) Social Statistics for a Diverse Society, SAGE, pp.40-43.

Freeman, A.M. (2003) The Measurement of Environmental and Resource Values: Theory and Methods, Resources for the Future, Washington.

Friedrich, R. and Bickel, P. (eds.) (2001) Environmental Costs of Transport, Springer-Verlag, Berlin.

Gulli, F. (2006) 'Social choice, uncertainty about external costs and trade-off between intergenerational environmental impacts: The emblematic case of gas-based energy supply decentralization', Ecological Economics, vol.57, pp.282-305.

Haynie, F.H. (1986) Atmospheric Acid Deposition Damage due to Paints, US-EPA Report, EPA/600/M-85/019.

Kucera,V., Pearce, D., and Brodin, Y.W. (1997) Economic Evaluation of Air Pollution Damage to Materials, Swedish Environmental Protection Agency, Stockholm, No.4761.

Lechon, Y., Cabal, H., Gomez, M., Sanchez, E. and Saez, R. (2002) 'Environmental externalities caused by $\mathrm{SO}_{2}$ and ozone in the metropolitan area of Madrid', Environment Science \& Policy, vol.5, pp.385-395.

Matus, K., Yang, T., Paltsev, S., Reilly, J. and Nam, K.M. (2008) 'Toward integrated assessment of environmental change: air pollution health Effects in the USA', Climatic Change, vol.88, pp.59-92.

Mestl, S.H.E., Aunan, K., Fang, J., Seip, H.M., Skjelvik, J.M. and Vennemo, H. (2005) 'Cleaner production a climate investment - integrated assessment in Taiyuan City, China', Journal of Clean Production, vol.13, pp.57-70.

Mirasgedis, S., Hontou, V., Georgopoulou, E. et al. (2008) 'Environmental damage costs from airborne pollution of industrial activities in the greater Athens, Greece area and the resulting benefits from the introduction of BAT', Environmental Impact Assessment Review, vol.28, pp.39-56.

Mitchel, R.C. and Carson, R.T. (1989) Using Surveys to Value Public Goods: the Contingent Valuation Method, Resources for the Future, Washington-DC.

Navrud, S. (2004) "Value transfer and environmental policy" in T. Tietemberg and H. Folmer (Eds.): The International Yearbook of Environmental and Resource Economics 2004/2005: a survey of current issues, Edgar Elgar Publishers, London.

Pearce, D.W. and Turner, R.K. (1990) Economics of natural resources and the environment, Hemel Hempstead, Harvester Wheatsheaf, Herst.

Rabl, A. and Holland, M. (2008) 'Environmental assessment framework for policy applications: Life cycle assessment, external costs and multi-criteria analysis', Journal of Environmental Planning and Management, vol.51, No.1, pp.81-105.

Rabl, A., Nathwani, J., Pandey, M. and Hurley, F. (2007) 'Improving policy responses to the risk of air pollution'. Taylor \& Francis, vol.70, pp.316-331.

Spiegel, M.R. and Stephens, L.J. (1999) Schaum's Outline of Theory and Problems of 
Statistics, McGraw-Hill, pp.36-38.

Sun, D. and Yang, W. (2007) 'Genetic algorithm solution of a gray nonlinear water environment management model developed for the liming river in Daqing, China', Journal of Environmental Engineering, vol.133, No.3, pp.287-293.

The World Bank (2007) Cost of Pollution in China: Economic Estimates of Physical Damages,

http://siteresources.worldbank.org/INTEAPREGTOPENVIRONMENT/Resources/China _Cost_of_Pollution.pdf.

Wu, F., Li, Z., Deng, N.S. et al. (2005) 'Economic development and eco-environment protection in central China - The case of Wuhan City', Fresenius Environmental Bulletin, vol.14, No.11, pp.1077-1080.

Zhang, Q-y., Wei, Y-m., Chen, Y-x. and Guo, H. (2007) 'Environmental damage costs from fossil electricity generation in China, 2000 similar to 2003', Journal of Zhejiang University-Science A, vol.8, No.11, pp.1816-1825. 